\title{
Climate Change and Health
}

Global climate is changing as manifested by rising surface temperature, melting ice and snow, rising sea level, increasing climate variability. For more than a century levels of $\mathrm{CO}_{2}$, methane and other green house gases are increasing, and it is now scientific reality that the temperature will rise $1.8-4^{\circ} \mathrm{C}$ and sea level will rise by $0.18-0.59 \mathrm{~m}$ by 2100 . It is now appreciated that ' $\mathrm{Climate}$ change is the biggest global health threat of the 21 st century'. 1

Climate change can cause health impact by a number of ways, for example climate change could have affect by increase of the mosquito born diseases like dengue, Chikungunya virus infection, malaria. In addition there will be effect on food, livestock change, energy, and thus the indirect effect of climate change will fall on health. ${ }^{2}$ Major projected health impacts of climate change in the poor countries has been provided by the Intergovernmental Panel on Climate Change (IPCC)'s Fourth Assessment Report (FAR) (Table). ${ }^{3}$

Climate change will make life of the coastal people difficult. World's poor will be the most affected by climate change. Bangladesh is going to be a major victim of such a phenomenon.
The change of temperature will have its impact as well: heat causes hyperthermia, cold causes hypothermia, draught causes famine. ${ }^{4}$

Injuries, displacement and deaths results from floods, and cyclones-tornado- example of increase in drowning and snake bite has been documented during floods in 2007 in Bangladesh.

Natural disasters highlight gaps in preparedness: Floods and other natural disasters are a fact of life in the Asia-Pacific region. Filipinos, Bangladeshis, and Chinese expect floods every year. A person living in the region is 25 times more likely to be affected by a natural disaster than is someone living in Europe or North America and four times more likely than someone living in Africa. International agencies, governments, and communities aware of the need for disaster preparedness in this region.

"Tsunami of December 26, 2004, as a turning point for improvement in disaster management systems". Every body appreciated the preparation at all levelsub-national and local level of training and preparation.

Table

Projected major health impacts of climate change in low-income countries

\begin{tabular}{lc} 
Health effect & Confidence level \\
\hline $\begin{array}{l}\text { Increase in malnutrition and consequent disorders, including } \\
\text { child growth and development }\end{array}$ & High \\
$\begin{array}{l}\text { Increase in death, disease, and injury from heat waves, floods, storms, } \\
\text { fire, and drought }\end{array}$ & High \\
$\begin{array}{l}\text { Mixed effects on malaria, with some contractions balanced by } \\
\text { expanded geographic range and change in seasonality }\end{array}$ & Very high \\
Change in the range of some vectors of infectious diseases & High \\
$\begin{array}{l}\text { Increase in diarrhoeal diseases } \\
\text { Increase in number of people exposed to dengue fever }\end{array}$ & Moderate \\
$\begin{array}{l}\text { Decrease in cereal crop productivity in low latitudes for even small } \\
\text { local temperature increases }\end{array}$ & Low \\
\hline
\end{tabular}


"Bangladesh has long been the leader in disaster risk management and one of the key aspects of their work is the strong link between early warning, communication of that warning, and evacuation plans. There are cyclone shelters all over the country, which are built in consultation with communities. The relay of cyclone and flood warnings is through a community channel as well." Although 500000 people were killed by the 1972 cyclone, and another 140000 by the 1991 cyclone, Bangladesh has managed to get their casualty numbers down to an estimated 4000-5000 in 2007's cyclone SIDR. The numbers are still very high. "The country is still embarking on building more of these double-purpose cyclone shelters". "The system can evacuate over 300 000 people in $48 \mathrm{~h}$-it is that well organized."

World Health Assembly 2008 addressed the importance of climate change and health: ${ }^{5}$

"The scientific evidence continues to mount,", "the climate is changing, the effects are already being felt, and human activities are a principal cause."

There is an urgency of adapting health systems to deal with the health risks of climate change-risks that will increase in future, particularly in vulnerable geographic regions and in poorly resourced populations.

Weather-sensitive disease events give a clear preview of the health impacts of climate change. For example, major heat waves have exacted heavy tolls of extra deaths in many countries this decade.

Response of the health sector will need to be undertaken in wide collaboration with many other sectors of government and social action.

The health sector, in general, has been slow to perceive the enormous significance of global climate change, as a threat to Earth's life-support systems, including the provision of water, food, clean air, and stable ecosystems-and, therefore, to human wellbeing, health, and survival.

How climate change jeopardises the achievement of the Millennium Development Goals, especially those that relate directly to health outcomes: infectious diseases, hunger and under nutrition, and child and maternal mortality.

The Assembly's resolution lays out a five-point agenda of research and action. First, fuller documentation of the risks to health and of differences in vulnerability between and within populations. Second, development of health protection strategies. Third, identification of the health co-benefits of actions taken to reduce greenhouse gas emissions or, in other sectors, to adapt to climate change. Fourth, development of decisionsupport tools and systems to predict the impact of climate change for member states. And fifth, estimation of the financial costs of actions and inactions in relation to health.

The health sector will be the source of much crucial information and understanding about the human consequences of climate change.

The different stakeholders in the health sector, doctors, nurses and other practitioners, administrators, public health personnel are to appreciate the importance of the issue and they have to: 6

- Promote recognition of the main health threats from climate change.

- Find the win-win actions that promote health as they reduce climate change - e.g. more active transport in automobile-dependent cultures will improve air quality, decrease greenhouse gas emissions and combat obesity.

- Stress the health sector's direct responsibility to respond to the threats to health that climate change is posing to the population.

- Provide an example of how the health sector can demonstrate carbon neutral practice.

- Point out that many of the most effective interventions in protecting health from climate change are basic public health interventions.

- Include issues of climate-related health threats in general health training and continuing education modules.

It is now more and more appreciated that like many public health interventions prevention of health impact of climate change is possible. ${ }^{7}$ Primary prevention of health impact of climate change is mitigation. Mitigation involves reduced production and /or increased sequestration of green house gases. The responsibility of mitigation lies also with other than health ministry like ministry of communication and transport, works (architecture) and energy. 
Secondary and tertiary prevention of the health effect of climate change is adaptation. Adaptation refers to activities that preserves function and health in the face of existing climate change and here the responsibility lies with the Ministry of Health and Family Welfare.

The health sector in poor countries are already in stress to cope with existing health problems related to communicable and non communicable diseases. In order to adapt the new health threats of climate change lots to be done in different areas of health service delivery. Bangladesh is in a crucial position and we have to act now to protect our population from the health impacts of climate change. In the first place as an important member of the health professional we have to convince ourselves that it is a reality and we have to continue to communicate in various ways of the health benefits of 'low-carbon living' which has far reaching impact $^{8}$. Health care professionals are in better position to promote health benefit of clean cooking and walking or bicycling which will lead to reduction of respiratory illness and coronary heart disease. ${ }^{9}$ At the same time we have to advocate and continually generate evidence on priority basis by various studies related to impact of climate change on climate-sensitive diseases including monitoring and utilize the gathered knowledge in protecting the community by a concerted effort.

(J Bangladesh Coll Phys Surg 2010; 28: 1-3)

M A Faiz ${ }^{1}$, Quazi Tarikul Islam ${ }^{2}$

Professor of Medicine, ${ }^{1}$ Sir Salimullah Medical College, ${ }^{2}$ Dhaka Medical College Dhaka, Bangladesh.

\section{References:}

1. Costello A, Abbas M, Allen A, et al. (2009) Lancet and University College London Institute for Global Health Commission: managing the health effects of climate change. Lancet; 373: 1693-733.

2. McMichael AJ, Haines A, Sloof R, Kovats S, eds. Climate change and human health. Geneva: WHO/UNEP/WMO, 1996.

3. Intergovernmental Panel on Climate Change. Climate change 2007: impacts, adaptation and vulnerability. Contribution of Working Group II to the Fourth Assessment Report of the Intergovernmental Panel on Climate Change. Parry ML, Canziani OF, Palutikof JP, van der Linden PJ, Hanson CE, eds. Cambridge UK: Cambridge University Press, 2007. www.ipcc.ch/ipccreports/ar4-wg2.htm.

4. Haines A, Kovats R S, Campbell-Lendrum D, Corvalan C (2006). Climate change and human health: impacts, vulnerability, and mitigation, Lancet; 367: 2101-09.

5. WHO. The impact of climate change on human health. April 7, 2008. http://www.who.int/ mediacentre/news/ statements/ 2008/s05/en/index.html.

6. WHO (2008) Protecting Health from Climate Change A toolkit for event organizers. World Health Day 2008

7. St. Louis M E, Hess J J, (2008). Climate Change: Impacts on and Implications for Global Health. Am J Prev Medicine; 35: $527-538$

8. Lim V, Stubbs J W, Nahar N, Amarasena N, Chaudry Z U, et al. (2009). Politicians must heed health effects of climate change. Lancet; 374: 973.

9. Wilks M (2010). "Greenwash" at the climate change summit in Copenhagen: Failure of leadership challenges doctors to lead by example. BMJ 340: 4-5. 